\title{
Miten torjua eriarvoisuutta monikulttuurisissa terveydenhuollon työyhteisöissä?
}

\author{
LAURA HIETAPAKKA
}

Ulkomaalaistaustaisten terveydenhuollon työntekijöiden määrä Suomessa on kasvanut jatkuvasti 2000-luvulla, vaikka heidän osuutensa onkin edelleen pieni verrattuna moniin muihin Euroopan maihin. Vuonna 2012 Suomessa terveydenhuollossa työskentelevistä lääkäreistä syntyperältään muita kuin suomalaisia oli 8,4 prosenttia ja sairaanhoitajista runsas kolme prosenttia. (1.) Kansallisessa kyselyssä suomalaisista lääkäreistä 66 prosenttia ja hoitajista 43 prosenttia ilmoitti työyhteisössään työskentelevän ulkomaalaistaustaisia työtovereita (2).

Ulkomaalaistaustaiset ovat suomalaistaustaisten tavoin oikeutettuja yhdenvertaiseen kohteluun suomalaisessa terveydenhuollossa (3). Tutkimusten mukaan ulkomaalaistaustaiset ammattilaiset ovat kuitenkin kohdanneet eriarvoisuutta jo ennen työllistymistään. Ongelmia on ollut esimerkiksi rekrytointiprosesseissa, ammatinharjoittamiseen vaadittavan toimiluvan saamisessa ja työyksikön toimintaan liittyvässä perehdytyksessä (4-6). Osa työssä aloittaneista ulkomaalaistaustaisista ammattilaisista on kohdannut epäilyjä ammattiosaamisestaan ja luottamuksen puutetta (6-7). Työyhteisöissä ulkomaalaistaustaiset ammattilaiset ovat kohdanneet syrjintää erityisesti potilaiden ja omaisten taholta, mutta myös työtovereiden taholta. $(2,8$.) Toisinaan ulkomaalaistaustaisille ammattilaisille on delegoitu heidän työhönsä kuulumattomia tehtäviä, kuten lähihoitajille siivousta (6).

Ulkomaalaistaustaisten ja suomalaistaustaisten ammattilaisten välisen eriarvoisuuden torjumisesta on varsin vähän linjauksia suomalaisissa terveydenhuollon työyhteisöissä. Vertailun vuoksi esimerkiksi jo vuodelta 1992 peräisin olevassa laissa potilaan oikeuksista (kolmas pykälä) todetaan, että " potilaan äidinkieli, hänen yksilölliset tarpeensa ja kulttuurinsa on mahdollisuuksien mukaan otettava hänen hoidossaan ja kohtelussaan huomioon" (9). Ei ole olemassa lakia, jossa vastaavalla tavalla taataan ulkomaalaistaustaiselle työntekijälle, että hänen kulttuurinsa otetaan työyhteisössä huomioon. Suomalaisissa työyhteisöissä ei ole erityisen hyvin valmistauduttu kohtaamaan ulkomaalaistaustaisia ammattilaisia. Eriarvoisuutta tuottavien tilanteiden ja toimintatapojen esille nostaminen antaa mahdollisuuden kehittää niihin ratkaisuja (10).

\section{OMAN JA MUIDEN KULTTUURIEN YMMÄRTÄMINEN}

Sekä kansainvälisissä että kotimaisissa tutkimuksissa on havaittu, että valtaväestö näkee ulkomaalaistaustaisten ammattilaisten tehtävänä sopeutua kohdemaan kulttuuriin, tapoihin ja ammatillisiin käytäntöihin (11-12). Kulttuurien moninaisuuden ei oleteta muuttavan kohdemaan työyhteisön käytäntöjä, eikä työyhteisön toimintaan liittyviä oppimistarpeita ole nähty molemminpuolisina vaan oppiminen on ollut vain ulkomaalaistaustaisten ammattilaisten tehtävä (12).

Tavoiteltaessa monikulttuurisesti yhdenvertaista työyhteisöä olisi tärkeää lisätä kaikkien työntekijöiden kulttuuritietoisuutta ja yhteistä keskustelua toimintatavoista. Esimerkiksi ulkomaalaistaustaiset työntekijät ovat voineet yhteisissä tilaisuuksissa kertoa suomalaistaustaisille työtovereilleen omasta kulttuuristaan ja maansa terveydenhuollon järjestämistavoista (13-14). Parhaimmillaan oman ja muiden kulttuurien ymmärtäminen edesauttaa molemminpuolista tutustumista, ymmärrystä ja olemassa olevien eriarvoistavien tai sellaisiksi koettujen käytäntöjen esille nostamista tai kulttuuristen toiveiden esille tuontia. 


\section{SAMANLAISESTA KOHTELUSTA MYÖNTEISEEN ERITYISKOHTELUUN}

Yhdenvertaisuuden on suomalaisissa työyhteisöissä usein virheellisesti tulkittu tarkoittavan kaikkien työntekijöiden samanlaista kohtelua. Monikulttuurisissa työyhteisöissä samanlainen kohtelu voi jopa lisätä ulkomaalaistaustaisten ja suomalaistaustaisten työntekijöiden välistä eriarvoisuutta. Vaatimus täydellisen suomen puhumisesta ja ymmärtämisestä on yksi esimerkki eriarvoistavasta käytännöstä (8). Toimiakseen suomalaisten asiakkaiden ja potilaiden kanssa terveydenhuollon työssä tarvitaan suomea, jota opitaan parhaiten työtä tekemällä ja työyhteisön jäsenenä olemisella. Kaiken työssä tarvittavan tiedon olemassa olo ja kommunikointi vain suomeksi voi kuitenkin olla perehtymisvaiheessa ulkomaalaistaustaiselle työntekijälle varsin kuormittavaa. Ulkomaalaistaustaiset työntekijät ovatkin toivoneet, että perehdyttämisessä olisi mahdollista käyttää englantia apukielenä ja suomea käytettäessä puhua selkeästi ja hitaasti. (12.)

Erityisesti uusien ulkomaalaistaustaisten työntekijöiden perehdytyksessä voitaisiin toteuttaa niin sanottua myönteistä erityiskohtelua. Tällä viitataan erityistoimenpiteisiin, joiden tarkoituksena on tosiasiallisen yhdenvertaisuuden edistäminen tai syrjinnästä johtuvien haittojen ehkäiseminen (15). Myönteistä erityiskohtelua on toteutettu onnistuneesti muutamissa suomalaisissa terveydenhuollon työyhteisöissä. Esimerkiksi ulkomaalaistaustaisten lääkärien vastaanotoille on työn alkuvaiheessa voitu ohjata normaalia vähemmän potilaita ja heidän mentorikseen on nimetty kokenut seniorilääkäri (16).

\section{KULTTUURISTEN JA USKONNOLLISTEN TARPEIDEN TOTEUTTAMINEN TYÖSSÄ}

Työntekijän oikeutta toimia oman uskonnollisen vakaumuksensa mukaan on pidetty tärkeänä myös suomalaisessa terveydenhuollossa. Esimerkiksi huivin käyttö työssä on sallittua ja alkoholittomia käsidesinfektioaineita on mahdollista ottaa käyttöön jos työntekijän uskonto sitä edellyttää. Käytännössä terveydenhuollon työssä haasteet liittyvät tilanteisiin, joissa työntekijän uskontoon liittyvä tarve on ristiriidassa organisaation hygieniamääräyksien, työ- tai potilasturvallisuuden tai työyksikön työtehtävien organisoinnin kanssa. Viimeksi mainittuun liittyen eräässä suomalaisessa organisaatiossa jouduttiin tekemään linjaus siitä, että työntekijöitä, jotka eivät pysty syöttämään potilaalle sianlihaa, ei voida palkata hoitajan työhön (13).

Tarve löytää luovia ratkaisuja työn toteuttamisen ja työntekijän vakaumuksen yhteensovittamiseksi todennäköisesti lisääntyy tulevaisuudessa Suomessakin. Kansainvälisessä tutkimuksessa alan esimiehiä rohkaistaan tunnistamaan työntekijöiden erilaisia hengellisiä tarpeita ja pohtimaan, voitaisiinko niiden toteuttaminen mahdollistaa työyhteisössä osana organisaatiokulttuuria (17).

\section{ASIAKKAIDEN JA POTILAIDEN ENNAKKOLUULOIHIN VAIKUTTAMINEN}

Suomalaisia terveydenhuollon työyhteisöjä on tutkimuksissa moitittu siitä, että ne eivät tee tarpeeksi asiakkaiden ja potilaiden ennakkoluuloisesta suhtautumisesta aiheutuvan eriarvoisuuden estämiseksi $(6,8)$. Esimiehet ovat tietoisia siitä, että osa erityisesti iäkkäimmistä asiakkaista vierastaa heikompaa suomea puhuvaa tai ei-suomalaisen näköistä työntekijää. Työyhteisöissä suomalaisten asiakkaiden mielipiteiden muuttaminen on kuitenkin koettu hyvin hankalaksi (8), vaikka onnistuneitakin kokemuksia asiakkaiden ennakkoluulojen murtumisesta on raportoitu (2).

Toisinaan asiakkaiden ja työntekijöiden oikeudet voivat myös olla keskenään ristiriidassa. Ajankohtainen esimerkki tästä liittyy valinnanvapauteen terveydenhuollossa. Miten ratkaistaan tilanne, jossa potilas kieltäytyy vastaanottamasta hoitoa ulkomaalaistaustaiselta työntekijältä? Keväällä 2016 uutisoitiin päätöksestä, jossa Helsingin ja Uudenmaan sairaanhoitopiiri (HUS) antoi potilaan vaihtaa lääkäriä edes tapaamatta häntä (18). Potilas oli havainnut lääkärin ulkomaalaistaustaiselta kuulostavan nimen ja ilmoittanut suostuvansa tulemaan vain suomalaistaustaisen lääkärin vastaanotolle. Kyseinen ulkomaalaistaustainen lääkäri koki tämän HUS:n toimintatavan myötä joutuneensa rasistisen syrjinnän kohteeksi. Pohdittavaksi jää, kumpi arvovalinta lopulta on tärkeämpi, potilaan oikeus valita häntä hoitava ammattilainen vai ulkomaalaistaustaisen työntekijän oikeus syrjimättömyyteen (ks. myös 6,18 ). 


\section{ASENNEMUUTOKSESTA KOHTI RAKENTEELLISIA RATKAISUJA}

Eriarvoisuuden torjuminen pohjautuu pitkälti avoimuuteen, asenteiden ja oman toiminnan muuttamiseen, kulttuuriseen sensitiivisyyteen ja eri kulttuurien (myös oman) vaikutusten tunnistamiseen ja ymmärtämiseen. Yksilölliset asenteet ja teot eivät kuitenkaan yksinään riitä terveydenhuollossa, jonka toiminta on perinteisesti hyvin hierarkkinen ja säädelty (esim. 6). Terveydenhuollon työpaikoille tarvitaan nykyistä enemmän rakenteita ja institutionaalisia käytäntöjä, joilla voidaan edistää ulkomaalaistaustaisten ammattilaisten työyhteisöön pääsyä ja pysymistä sen tasavertaisena jäsenenä. Tällaisten käytäntöjen luominen ei ole aina helppoa. Koska institutionaaliset käytännöt jäävät usein työpaikkoja koskevan virallisen säätelyn ulkopuolelle, on vaarana että ne mahdollistavat epätasa-arvoisten käytäntöjen syntymisen työpaikoilla. (6.) Samalla ne jättävät helposti terveydenhuollon esimiehet ja yksiköt yksin vastuuseen koko alaa koskevien linjauspäätösten tekemisestä (13).

\section{LÄHTEET}

(1) Ailasmaa R. Terveys- ja sosiaalipalveluiden henkilöstön kansainvälinen liikkuvuus 2012. Tilastoraportti $12 / 2015$. Terveyden ja hyvinvoinnin laitos.

(2) Hietapakka L, Elovainio M, Heponiemi T, Lämsä R, Aalto A-M, Kuusio H. Ulkomaalaisena ammattilaisena suomalaisessa terveydenhuollossa. Teoksessa Aalto A-M, Elovainio M, Heponiemi T, Hietapakka L, Kuusio H, Lämsä R. (toim.) Ulkomaalaistaustaiset lääkärit ja hoitajat suomalaisessa terveydenhuollossa - haasteet ja mahdollisuudet. THL raportteja 7/2013. Juvenes Print, Suomen Yliopistopaino Oy, Tampere, 58-75.

(3) ETENE. Monikulttuurisuus Suomen terveydenhuollossa. Valtakunnallinen terveydenhuollon eettinen neuvottelukunta (ETENE), 5. kesäseminaari, Helsinki, 17.8.2004, Helsinki: Yliopistopaino Oy; 2004.

(4) Lämsä R, Manderbacka K, Kuusio H, Aalto A-M, Elovainio M. Ylilääkärien ja ulkomaalaistaustaisten lääkärien kokemuksia toimilupaprosessista. Suom Lääkäril 2012; 37 : 2555-2560.

(5) Näre L. Hoivatyön glokaaleilla markkinoilla: filippiiniläisten sairaanhoitajien rekrytointi Suomeen jälkikolonialistisena käytäntönä. Sosiologia 2012; 3: 206-221.

\section{LOPUKSI}

Terveydenhuollon työyhteisöjen monikulttuuristuminen Suomessa on Eurooppaan verrattuna vielä nuori ja pienimuotoinen ilmiö, jonka uskotaan kasvavan kuitenkin koko ajan. Muualta tulleet ammattilaiset ovat tuoneet suomalaisten terveydenhuollon työyhteisöjen pohdittavaksi asioita, joita niissä ei ole aiemmin tarvinnut miettiä. Siksi myöskään valmiita ratkaisuja tai käytäntöjä erilaisiin tilanteisiin ei ole välttämättä vielä ehditty kehittämään. Monikulttuuriseen terveydenhuoltoon liittyvistä asioista olisi tarpeen keskustella avoimesti monitieteisessä ympäristössä ja yhdessä sosiaali- ja terveydenhuollon käytännön toimijoiden kanssa.

Kirjoitus on toteutettu osana Strategisen tutkimuksen neuvoston rahoittamaa COPE-hankekonsortiota "Osaavan työvoiman varmistaminen sosiaali- ja terveydenhuollon murroksessa" (303607).

(6) Laurén, J, Wrede S. Työkäytännöt ja institutionaalinen rasismi - lähihoitajien työ. Teoksessa Wrede S, Nordberg, C. (toim.) Vieraita työssä: työelämän etnistyvä eriarvoisuus. Helsinki: Gaudeamus, Palmeniasarja 70; 2010, 172-192.

(7) Nieminen S. Neuvotteluja ammatillisesta jäsenyydestä: maahanmuuttajasairaanhoitajat terveydenhuollon yhteisöissä. Teoksessa Wrede S, Nordberg C. (toim.) Vieraita työssä: työelämän etnistyvä eriarvoisuus. Helsinki: Gaudeamus, Palmenia-sarja 70; 2010, 147-171.

(8) Näre L. Ideal Workers and Suspects: Employers' Politics of Recognition and the Migrant Division of Care Labour in Finland. Nord J Migr Res 2013; 3: 72-81. https://doi.org/10.2478/v10202-012-0017-5

(9) Laki potilaan asemasta ja oikeuksista 17.8.1992/785. http://www.finlex.fi/fi/laki/ ajantasa/1992/19920785

(10) Wrede S. Suomalainen työelämä, globalisaatio ja vieraat työssä. Teoksessa Wrede S, Nordberg C. (toim.) Vieraita työssä: työelämän etnistyvä eriarvoisuus. . Helsinki: Gaudeamus, Palmeniasarja 70; 2010, 7-31.

(11) Hunt B. Managing equality and cultural diversity in the health workforce. J Clin Nurs 2007; 16: 2252-2259.

https://doi.org/10.1111/j.13652702.2007.02157.x 
(12) Vartiainen-Ora P. Filippiiniläisen sairaanhoitajan tie kohti suomalaisen työyhteisön jäsenyyttä. Ammattik Aikak 2015; 17: 12-26.

(13) Hietapakka L, Elovainio M, Lämsä R, Kuusio $\mathrm{H}$, Aalto A-M. Perusterveydenhuollon esimiesten kokemuksia ulkomaalaistaustaisesta terveydenhuoltohenkilöstöstä: voimavara vai ei? Sosiaalilääk Aikak 2013; 50: 272-284.

(14) Xiao L D, Willis E, Jeffers L. Factors affecting the integration of immigrant nurses into the nursing workforce: A double hermeneutic study. Int J Nurs Stud 2014; 51: 640-653. https://doi.org/10.1016/j.ijnurstu.2013.08.005

(15) Yhdenvertaisuuslaki 30.12.2014/1325. http:// www.finlex.fi/fi/laki/ajantasa/2014/20141325

(16) Kuusio H, Lämsä R, Aalto A-M, Manderbacka K, Keskimäki I, Elovainio M. Inflows of foreignborn physicians and their access to employment and work experiences in health care in Finland: qualitative and quantitative study. Hum Resour Health 2014; 12:41: 4-11.

https://doi.org/10.1186/1478-4491-12-41
(17) Pirkola H, Rantakokko P, Suhonen M. Workplace spirituality in health care: an integrated review of the literature. J Nurs Manag 2016; 24: 859-868. https://doi.org/10.1111/jonm.12398

(18) Suomen Kuvalehti 2.4.2016. Sairaala hyväksyi rasistisen syrjinnän: Potilas sai kieltäytyä ulkomaalaistaustaisesta lääkäristä. Luettu 29.3.2017. https://suomenkuvalehti.fi/jutut/ kotimaa/sairaala-hyvaksyi-rasistisen-syrjinnanpotilas-sai-kieltaytya-ulkomaalaistaustaisestalaakarista/

\section{LAURa Hietapakka}

VTM, sairaanhoitaja AMK, tutkija

Terveyden ja hyvinvoinnin laitos 